\title{
PRACTICAL EXPERIENCES, REGULATORY PRINCIPLES AND ISSUES OF THE TERRITORIAL DELIMITATION OF DEVELOPMENT POLICY IN HUNGARY
}

\author{
István FINTA ${ }^{\mathrm{a}}$, Péter DOMBI ${ }^{\mathrm{b}}$ \\ ${ }^{a}$ Institute for Regional Studies, Centre for Economic and Regional Studies; Papnövelde u. 22., H-7621 \\ Pécs, Hungary; finta.istvan@krtk.hu \\ ${ }^{b}$ Institute for Regional Studies, Centre for Economic and Regional Studies; Papnövelde u. 22., H-7621 \\ Pécs, Hungary; dombi.peter@krtk.hu
}

Cite this article: Finta, I., Dombi, P. (2021). Practical experiences, regulatory principles and issues of the territorial delimitation of development policy in Hungary. Deturope, 13(2): 101-124.

\begin{abstract}
Both at national and EU level, the differentiation of specific territorial units is a key issue in development policy. The objective of the delimitation at the highest legal level is to mitigate territorial differences; it is intended to provide support for the delimited (beneficiary) territorial units. Benefits (e.g. the rate and intensity of support) are fundamentally influenced by development and growth opportunities, so the methods and the results of delimitation are both politically and professionally sensitive. This is particularly important for rural areas and rural development, because the beneficiaries' delimitation - or lack thereof is most affected by these regions. Hungary has been operating and developing a delimitation system since the '90s, the elements of which are at community level can serve as a model, and can be well-utilized. For this purpose, the paper presents the regulatory starting points and principles of spatial delimitation, the statistical methods used so far, the range of data used, and the problems that can be associated with the methods and data used so far. The authors propose a data set and a calculation method that more faithfully reflects the real situation of territorial development, which would enable development resources to better contribute to reducing territorial disparities.
\end{abstract}

Keywords: territorial-rural development, development policy, delimitation, beneficiary areas, development, backwardness

\section{INTRODUCTION}

The purpose of the study is to examine and evaluate the Hungarian legal regulation and practice of the delimitation of beneficiary areas, which is based on the Hungarian National Development and Regional Development Concept (OFTK), being in relation with the European Union's cohesion policy and the principles and objectives of the Hungarian National Development and Regional Development Concept (OFTK). In the case of Hungary, the establishment of the legal classification system cannot be regarded as something being without past precedence; the 
establishment of prior classification systems is based on the interpretations of several excellent papers (see: Faluvégi \& Tipold, 2009, 2012). Current investigations primarily focus on fixed principles in the sense that

- to what extent they can be considered complete or complementary (supplementary)

- whether the demands and requirements during the practical application fully cover the legislator's requirements,

- are there any proposals that could contribute to making legislation more consistent in order to ensure long-term stability of regulation (avoiding frequent modification) and to take greater account of underlying living conditions (adaptation to facts, actual situations, realities, demands).

The article focuses not on delimitation itself but rather on beneficiary rating, which defines the scope of the study and the content of this paper. The literature approaches different regional delimitations with different purposes and by different analysis methods. A number of synthetic works or even regional classifications have been developed over the last decades, where, for example, the authors dealt with the poverty, the underdevelopment or the peripheral status of various territorial units, where the status of regional development beneficiary played more or less important role.

The methods used also fit into the objectives of the study, such as the detailed presentation of statistical analyses, but the investigations were not aimed at the revolutionary modification of rounded-up calculations having been revised many times and in many ways.

Of the factors frequently mentioned in literature (territorial level, timeliness, development, backwardness indicators, the "complex methods of the production" of complex indicators Pénzes, 2014, p. 7), this article intends to focus on none; the issues of territorial level are dealt with only partially, primarily in the context of rural specificities.

The methods used in the study - in line with the goals of territorial and rural development are multidisciplinary. On the one hand, they rely on the methodology of legal analysis (since territorial delimitation is a matter of legal regulation in both Community and Hungarian legislation) and, on the other hand, on the theory and practice based on decades of statistical analyses and methods that are targeted at the geographical delimitation of disadvantaged areas in Hungary. In line with the EU development policy principle of geographical concentration, the aim of the study is to develop a methodology that (better) guarantees the identification of lagging regions so that development resources aimed at reducing disparities can actually help these regions to develop. This will be facilitated by the practical experience gained in 
implementing the LEADER programme, which covers the whole of Hungary's rural areas and includes the entire territory of disadvantaged areas.

\section{MAJOR FINDINGS IN INTERNATIONAL LITERATURE}

'Regional development' has always been one of the central concepts of human geography. In economic-related definitions, the common feature is to emphasize higher productivity, higher levels of employment and consumer spending, and shifting the economy to the third sector, while broader social aspects include the education, health and safety of population, as well as the role of environmental resources (Bossel, 1996, 1999).

The degree of the expansion of the concept of 'regional development' is presented by Mabogunje (1980), who defined the following time steps for interpreting the term: (1) economic growth, (2) modernization, (3) distribution justice, and (4) socio-economic transformation.

Extending the range of ingredients naturally makes the measurement difficult (Booysen, 2002; Saisana et al., 2005; OECD, 2008). There have already been numerous objections to GDP expressing economic development (see Lepenies, 2016; Stiglitz \& Walsh, 2006; Davies, 2014; Widuto, 2016). One of the most striking opposites is that the main problem of standard economic indicators (GDP, unemployment) is that they measure rather the consequences than the causes (Lipshitz, 1993). Apart from the general problems of GDP well known in the economy, GDP data on a regional or even a smaller administrative unit are difficult to be traced because they are largely based on estimates and can therefore seriously distort the data in the absence of accurate site data. For example, in the metropolitan agglomeration, due to inflowing commuters, the RGDP per capita calculation can be overestimated by up to $20 \%$ (Boldrin \& Canova, 2001).

There are many aspects to the selection of the indicators of development measurement in the literature. Hagerty et al (2001) lists 14 criteria on which the suitability and usefulness of the indicators included in the index can be judged. Among the criteria, one of the most controversial issues considered by the authors, the principle that the index should reflect the multidimensional phenomenon to be measured in the form of a single number is worth emphasizing. On the one hand, there is a need for a "unique scale" for the sake of clear comparability, however, because combining the components immediately creates a kind of weighting, any arbitrary one-dimensional projection in the evaluation can result not only in a loss of information but also in an undesirable distortion. If we add that the construction is intended to be used indirectly - or just like in Hungarian practice - politically, it is immediately apparent 
that by over-emphasizing certain constituents, the development index may become manipulable.

With regard to the composition of the complex indicator, it is usually characteristic that for its generation sub indicators are selected in thematic groups. The most fundamental setting defines three thematic pillars, including the indices describing social, economic and physicalenvironmental conditions (Copust \& Crabtree, 1996; Vrtenová et al., 2009; Kutscherauer et al., 2010). The emphasis of this triple division may sometimes be easily communicated by the People, Prosperity, Planet motto (Hák \& Janoušková, 2013). The triple division is close to the system used in Hungarian practice, with four development blocks, socio-demographic, economic, housing and living conditions, and infrastructure development. However, several studies have been carried out with a more detailed, 7-10 component dimension (Ferrara \& Nistico, 2015; Salvatia et al., 2016; De Smedt, 2013). Of these, perhaps the best known is the so-called "Stiglitz report". In their paper, eight dimensions have been identified, whose inclusion is considered unavoidable when generating the ideal composite well-being indicator (Stiglitz et al., 2009).

Another important point to consider is the selection of the spatial scale for the development index. There are indicators that cannot be reliably formatted in certain size categories. In the case of small population, this is besides the already mentioned RGDP indicator, the indicator of the life expectancy of the population (Scherbov \& Ediev, 2011) or the number of enterprises per capita. It may also be that some factors favour certain economic activities, in other cases they may be irrelevant or potentially inhibiting (Wishlade \& Yuill, 1997).

There are countries (e.g. Croatia) where the legal regulation of spatial development confines itself to delimiting only a few special conditioned areas. This is not sufficient in itself, as regional policy can only be effective if it is applied in the same way in areas of homogeneous development (Bakaric et al., 2005). In countries where there are significant territorial differences between regions, e.g. Germany between the eastern and western parts or Italy, north and south of Italy, it occurs that regional policy includes regulations to be applied differently in the different parts of the country (Wishlade \& Yuill, 1997).

The presentation of the most important findings and research directions of international literature highlights those - significant - differences that characterize the different approaches of Hungarian practice, and possibly the internationally usable elements of sample value. Such differences are as follows: 
- territorial scale (according to international practice regional level while - according to our experience - smaller territorial units can better express territorial differences and the direction of change);

- the range of data used (preferring basic data and original sources that are most resistant to distortions rather than using derivative data, secondary resources, and multiple computed values);

- a model applicable only in theory or a model applicable in practice as well (besides the usefulness of the theoretical models, the Hungarian solution - or the study - focuses on practically operational / operable solutions in the area of rural development);

\section{THE RELATIONSHIP BETWEEN DEVELOPMENT POLICY AND TERRITORIAL DELIMITATION AT EUROPEAN UNION LEVEL}

Within the European Union's development policy, spatial focus has played a prominent role in every programming period. The definition of the territorial units of different scales, the coherence of territorial units and development policy goals, the adaptation of development resources to territorial units with different abilities, and their fundamental modification or even fine-tuning, are all evergreen issues in Community development policy.

During the definition of any territorial unit, area in any aspect, the first fundamental question is the purpose of delimitation and classification. The legal basis of the European Union or of any EU spatial development intervention is Article 174 of the Treaty on the Functioning of the European Union (TFEU), which aims at reducing disparities between territorial units with varying degrees of development. In order to achieve this fundamental objective in the best possible way within the cohesion policy that serves this purpose, a number of solutions and principles have been developed at Community level (Farkas, 2018). One such principle was concentration, which is closely related to the question of territorial delimitation.

It is well known that the concept of concentration is essentially composed of three elements, thematic, financial and territorial concentration. Some aspects of territorial units can be taken into account even on all three elements, but territorial and financial concentration, in the areas where cohesion policy is to focus, are present in any case. In order to ensure that the most disadvantaged areas have a chance to catch up, they should be raised and differentiated, and if possible - subsidized differently, from the average. The positive discrimination, or more precisely the geographical delimitation, means territorial concentration, and discriminatory subsidization means the enforcement of financial concentration. (In the case where certain 
Finta, I., Dombi, P.

programmes may only be implemented in the beneficiary areas - or in their further differentiated units - the thematic concentration, as one of the means of achieving the objective of cohesion policy, is also linked to the classification system, or more specifically, to the system of criteria that may influence or determine the elements of the targeted correct classification process). The beneficiary classification of each territorial unit is thus a focus which, in line with the principle of concentration, ensures the relevance of the area and rural development of this particular region type.

The 2014-2020 programming period - at Community and national level - has brought about changes in the fact that territorial cohesion objective set out in Article 174 TFEU should contribute not only to cohesion policy instruments (the individual funds) but also to the Common Agricultural Policy Funds ${ }^{1}$ as well.

The emphasis on Community legislation was important not only because the development potential of our country is determined by the goals and resources set at Community level but also because there is no perceptible difference between the classification of beneficiaries in the National Development and Regional Development Concept and the objectives set at Community level:

"bg) the resources available for the most disadvantaged districts and settlements from the point of regional development, should be utilised on the basis of specific rules of subsidization,

bh) the applications of the most disadvantaged districts and municipalities submitted for regional development should be given preference during the evaluation of tenders in order to facilitate their catching-up"(Decision No 1/2014 (I. 3.) OGY).

In delimiting and classifying each territorial unit, the first and fundamental goal is to define its underdeveloped - or its inverse - developed status.

\footnotetext{
${ }^{1}$ Article 174 of the Treaty on the Functioning of the European Union (TFEU) provides that the Union shall aim to strengthen economic, social and territorial cohesion in order to reduce disparities between the levels of development of the various regions and the backwardness of the less favoured regions or islands and pay particular attention to rural areas, regions affected by industrial transformation and regions with severe and persistent natural or demographic handicaps. Article 175 of the TFEU provides for the Union to support the achievement of these objectives through the action of the Guidance Section of the European Agricultural Guidance and Guarantee Fund, the European Social Fund, the European Regional Development Fund, the European Investment Bank and other instruments.
} 
Finta, I., Dombi, P.

\section{PROBLEMS WITH THE FULFILLMENT OF THE REQUIREMENTS OF HUNGARIAN REGULATION, THE COMPLEMENTARITY OF REQUIREMENTS (PRINCIPLES)}

In the majority of the principles enshrined in Hungarian legislation, it is possible to collect problems and solutions related to the classification of beneficiary areas around these fundamental principles. However, surveys have also pointed out that there may be some requirements (principles) which, at present, are not part of the existing legislation.

Hungarian legislation defines a number of - otherwise explicitly acceptable - requirements for statistical indicators that can be applied in the development level classification for territorial delimitation. However, the currently used range of indicators points to a problem that the literature relates to the requirement of independence. This means that the data / indicators chosen must be relatively independent of each other in order not to intensify their mutual effect for generating values that are far greater than the actual one and by this distorting the final result. This danger is highlighted in the literature as well (Pénzes, 2014, p. 41) and current experiences show that in the so-called infrastructure index group we may encounter such undesirable effects.

Regarding the indicators used in statistical calculations, the basic requirement of independence can be formulated as a regulatory requirement.

In the following, we are looking for the answers to the questions of their practical application and the questions related to the application of the Hungarian regulations (National Development and Regional Development Concept - NDRDC) in order to formulate proposals for legislation. The document - the NDRDC - is all the more significant since it provides the conceptual framework for the allocation of EU development funds to day (Somlyódyné Pfeil, 2017).

PRINCIPLE 1: According to the Decision, only the use of indicators that can be measured, verifiable, publicly available, accessible to all concerned and dynamic comparisons are acceptable.

As regards the indicators used, there are more than one that is not included in the publicly available TStar database published by the Central Statistical Office (life expectancy at birth, housing price, car-age). Some indicators are not known at settlement level, they are only known on district scale, and the access to, and the subsequent calculation of settlement data are unknown or unavailable. In Budapest, there may be a problem with sub-settlement level, i.e. the availability of district-level data in Budapest. In order that the data could be measurable, 
verifiable and accessible, it is necessary for them to comply with the requirement that they should be set up at settlement level and be included in the public databases.

The requirement against the coherence of the classification system may also mean that the data used during the different programming periods should be identical, otherwise the results cannot be compared and it is not possible to determine whether the differences in development between the different territorial units have decreased or increased. Unfortunately, this requirement has not been fulfilled in the last decade (Table 1). In each index group labelled as Group Indicator in the calculation formula, grey shaded cells were used to highlight the indicators belonging to a group with the same content, but indicated under different set of indicators during different time periods. (In the case of consistently designed and applied indexing systems, only a certain decrease or increase or minimal deviation would be observed, but in the present case, coincidences are rather a rarity.)

Table 1 Identities and differences between indicators used between 2007-2013 and 2014-2020

\begin{tabular}{|c|c|}
\hline $\begin{array}{l}\text { 2. Indicators and sets of indicators used for } \\
\text { beneficiary classification between } 2014-2021\end{array}$ & $\begin{array}{l}\text { Data range for the calculation of the complex } \\
\text { indicator measuring the socio-economic and } \\
\text { infrastructural backwardness / development of } \\
\text { micro-regions and settlements between } 2007-2013\end{array}$ \\
\hline $\begin{array}{l}\text { Set of indicators No. 1: Social and demographic } \\
\text { situation }\end{array}$ & I. Economic indicators: \\
\hline $\begin{array}{l}\text { Urbanity / rurality index (what proportion of the } \\
\text { population in the given district lives in a population } \\
\text { density of more than } 120 \text { inhabitants } / \mathrm{km}^{2} \text { ), \% }\end{array}$ & $\begin{array}{l}\text { The number of active economic organizations per } 1000 \\
\text { inhabitants }\end{array}$ \\
\hline $\begin{array}{l}\text { Mortality rate (number of deaths per thousand } \\
\text { inhabitants) (average of the last five years), \%o }\end{array}$ & $\begin{array}{l}\text { The number of guest nights in private and commercial } \\
\text { accommodation per } 1000 \text { inhabitants }\end{array}$ \\
\hline $\begin{array}{l}\text { Migration difference per thousand inhabitants } \\
\text { (average of the last five years), heads }\end{array}$ & The number of retail stores per 1000 inhabitants \\
\hline $\begin{array}{l}\text { The number of nursery and family day-care } \\
\text { facilities per ten thousand } 0-2 \text { years per capita }\end{array}$ & $\begin{array}{l}\text { The proportion of employed persons in agriculture from } \\
\text { all employees, } \%\end{array}$ \\
\hline $\begin{array}{l}\text { The rate of regular child protection benefit from the } \\
\text { permanent population aged } 0-24, \%\end{array}$ & $\begin{array}{l}\text { The number of employees in the service of all } \\
\text { employees, } \%\end{array}$ \\
\hline $\begin{array}{l}\text { The number of people living in active age (regular } \\
\text { subsidies for social assistance and employment) }\end{array}$ & Changes in the number of operating companies, $\%$ \\
\hline $\begin{array}{l}\text { Set of indicators No. 2: Housing and living } \\
\text { conditions indicators: }\end{array}$ & Local tax revenue of local governments, HUF \\
\hline The average price of used flats, HUF & $\begin{array}{l}\text { The number of scientific researchers and developers per } \\
1000 \text { inhabitants }\end{array}$ \\
\hline $\begin{array}{l}\text { The proportion of housing built during the last five } \\
\text { years from housing stock at end of period, } \%\end{array}$ & II. Infrastructure indicators: \\
\hline $\begin{array}{l}\text { The percentage of (residential) homes without } \\
\text { comfort, } \%\end{array}$ & $\begin{array}{l}\text { The proportion of apartments connected to the public } \\
\text { water supply system, } \%\end{array}$ \\
\hline $\begin{array}{l}\text { Per capita income per inhabitant as personal income } \\
\text { tax base, HUF }\end{array}$ & $\begin{array}{l}\text { The length of sealed canal network per } 1 \mathrm{~km} \text { of water } \\
\text { mains, meter }\end{array}$ \\
\hline $\begin{array}{l}\text { The number of passenger cars by persons, per age- } \\
\text { weighted thousand population }\end{array}$ & $\begin{array}{l}\text { Households consuming fixed gas as a percentage of } \\
\text { housing stock, } \%\end{array}$ \\
\hline
\end{tabular}


Finta, I., Dombi, P.

\begin{tabular}{|c|c|}
\hline $\begin{array}{l}\text { Set of indicators No. 3: Local economy and labour } \\
\text { market }\end{array}$ & $\begin{array}{l}\text { The proportion of homes involved in regular waste } \\
\text { collection, } \%\end{array}$ \\
\hline $\begin{array}{l}\text { The percentage of people aged } 18 \text { years and over, } \\
\text { with at least high school graduates, } \%\end{array}$ & An index of everyday access \\
\hline $\begin{array}{l}\text { The ratio of registered jobseekers to working age } \\
\text { population, } \% 2006 \text { average }\end{array}$ & $\begin{array}{l}\text { Number of telephone headquarters (ISDN) per } 1000 \\
\text { inhabitants }\end{array}$ \\
\hline $\begin{array}{l}\text { The proportion of permanent jobseekers registered } \\
\text { for a continuous period of at least } 12 \text { months from } \\
\text { the working population, } \%\end{array}$ & $\begin{array}{l}\text { The number of cable TV subscribers per } 1000 \\
\text { inhabitants }\end{array}$ \\
\hline $\begin{array}{l}\text { The percentage of registered jobseekers from the } \\
\text { working age population (annual average), } \%\end{array}$ & $\begin{array}{l}\text { The number of broadband subscribers per } 1000 \\
\text { inhabitants, heads }\end{array}$ \\
\hline $\begin{array}{l}\text { The proportion of permanent jobseekers registered } \\
\text { for at least } 12 \text { months permanently from the } \\
\text { working age population, } \%\end{array}$ & Access point for expressway nodes \\
\hline $\begin{array}{l}\text { The percentage of registered jobseekers with up to } \\
\text { primary school grades, } \%\end{array}$ & III. Social indicators: \\
\hline $\begin{array}{l}\text { The number of active enterprises per thousand } \\
\text { inhabitants }\end{array}$ & $\begin{array}{l}\text { The proportion of built 3-x-room apartments in the } \\
\text { period-end housing stock, } \%\end{array}$ \\
\hline The number of retail stores per thousand inhabitants & $\begin{array}{l}\text { The number of passenger cars per age of } 1000 \\
\text { inhabitants }\end{array}$ \\
\hline $\begin{array}{l}\text { The ratio of local tax revenue to local government } \\
\text { revenue from current year revenue, } \%\end{array}$ & $\begin{array}{l}\text { Migration margin; average annual population per } 1000 \\
\text { people in the period }\end{array}$ \\
\hline $\begin{array}{l}\text { Set of indicators No. } 4 \text { : Infrastructure and } \\
\text { environmental indicators: }\end{array}$ & Death rate (number of deaths per 1000 inhabitants) \\
\hline $\begin{array}{l}\text { The proportion of apartments connected to public } \\
\text { sewage collection network, } \%\end{array}$ & $\begin{array}{l}\text { Per capita income per inhabitant as personal income tax } \\
\text { base, HUF }\end{array}$ \\
\hline $\begin{array}{l}\text { The proportion of homes involved in regular waste } \\
\text { collection, } \%\end{array}$ & $\begin{array}{l}\text { Urbanity / rurality index (how many percent of the } \\
\text { population of the micro-region lives in a population } \\
\text { density of more than } 120 \text { inhabitants } / \mathrm{km}^{2} \text { ), \% }\end{array}$ \\
\hline $\begin{array}{l}\text { The number of broadband Internet subscribers per } \\
\text { thousand inhabitants }\end{array}$ & Population density, person $/ \mathrm{km}^{2}$ \\
\hline The ratio of built roads to all municipal roads, $\%$ & IV. Indicators of social and demographic situation: \\
\hline Access indicator to the county seat, in minutes & $\begin{array}{l}\text { Youth index (below } 15 \text { years of age as a percentage of } \\
\text { the } 60 \text {-x population), } \%\end{array}$ \\
\hline $\begin{array}{l}\text { Access indicator to the nearest express way nodes, } \\
\text { in minutes }\end{array}$ & The proportion of non-employed households, $\%$ \\
\hline & $\begin{array}{l}\text { Percentage of } 18 \text {-year-olds with at least high school } \\
\text { graduation, } \%\end{array}$ \\
\hline & $\begin{array}{l}\text { The average annual number of people receiving regular } \\
\text { social assistance by municipalities per } 1000 \text { inhabitants }\end{array}$ \\
\hline & $\begin{array}{l}\text { The proportion of people receiving regular child } \\
\text { protection support from the } 0-24 \text { year old population, } \%\end{array}$ \\
\hline & V. Employment indicators: \\
\hline & $\begin{array}{l}\text { The ratio of registered jobseekers to working age } \\
\text { population, } \% 2006 \text { average }\end{array}$ \\
\hline & $\begin{array}{l}\text { The proportion of permanent jobseekers registered for a } \\
\text { continuous period of at least } 12 \text { months from the } \\
\text { working population, \% }\end{array}$ \\
\hline & Activity rate, $\%$ \\
\hline
\end{tabular}

Source: the author's own edition. 
Regardless of the questionable application practice, there are some timeless indicators that seem to be able to characterize development after 30 years as well as they did it twenty years ago. When selecting indicators, time-resistance is a very important aspect, since this is a longterm comparability, a basis for coherence between indicator systems. At the same time, it is not uncommon, and even in all classifications, indicators have been identified to reflect actual policy preferences (e.g. telephone, gas supply, tourism). Once the individual factors have become available to the general population or the municipalities as a whole, or their existence can simply be handled as a common feature (e.g. phone), it is left out or may have been left out of the indices. At the same time, there are still indicators that are no longer so closely related to development level indicators as they were in the 90 's. Similar findings can be found in the literature (Jakobi, 2004, p. 7), but we cannot really answer the question that even if it is justified to take into account new factors, what proportion of them can be included in the calculations without violating the principle of comparability. It is also difficult to formulate the exact answer for this, but perhaps maximizing the ratio of new indicators up to $25 \%$ - and fixing everything at the level of regulation - would still be an acceptable compromise that would not interfere with the need for comparability.

It is also necessary to point out that the indicators currently used are static indicators, i.e., they display a fixed value for a particular time. The literature is not at all uniform in the use of either static or static and dynamic indicators (Money, 2014 vs. Harcsa, 2007). Of course, this question cannot be resolved here, but if we are able to visualize a pace and speed of change, it can provide meaningful information to the decision-maker about the way and direction of possible interventions. (E.g.: If we are able to demonstrate the rapidity of population decline for settlements with a population of less than 500, then it is possible to calculate for how much time there is still room for any meaningful intervention. From this point of view, it is indifferent to the decision-maker that all of this is achieved by using a dynamic indicator, or the static indicators are scanned at appropriate intervals.)

PRINCIPLE 2: The number of indicators used cannot be expanded unlimitedly and only indicators that capture the actual development of settlements and districts and effectively differentiate should be taken into account.

From the regime change up to the present day, in many cases, different number and content indicators and only statistical methods were used for classifying the different territorial units of beneficiaries. These classifications were experiments of different agendas and governments with differing policies (Table 2) to represent the content of development by still complex and often subjective means at territorial level (See Pénzes, 2014, p. 45; Nagy, 2011. p. 3). 
Table 2 The regulatory system and results of the classification of beneficiary areas

\begin{tabular}{|c|c|c|c|c|c|c|}
\hline Parliamentary & Government & Number of & \multicolumn{4}{|c|}{ Delimited area types } \\
\hline \multirow{4}{*}{$\begin{array}{l}\text { 84/1993. (XI. } \\
\text { 11.) OGY } \\
\text { (Repealed by } \\
\text { the 1997. XXI. } \\
\text { Act on Regional } \\
\text { Development } \\
\text { and Physical } \\
\text { Planning.) }\end{array}$} & $\begin{array}{l}\text { 161/1993. (XI. } \\
\text { 17.) Govt. } \\
\text { Decree }\end{array}$ & \multirow[b]{4}{*}{$\begin{array}{c}11 \\
\text { indicators }\end{array}$} & \multirow{2}{*}{$\begin{array}{l}\text { economically- } \\
\text { socially } \\
\text { backward } \\
\text { settlement }\end{array}$} & \multirow{2}{*}{$\begin{array}{l}\text { settlements of a } \\
\text { district with } \\
\text { above the } \\
\text { national average } \\
\text { by } 1.5 \text { times } \\
\text { unemployment } \\
\text { rate }\end{array}$} & & \\
\hline & $\begin{array}{l}\text { 61/1995. (V. } \\
\text { 30.) Govt. } \\
\text { Decree }\end{array}$ & & & & & \\
\hline & $\begin{array}{l}\text { 80/1996. (VI. } \\
\text { 7.) Govt. } \\
\text { Decree }\end{array}$ & & \multirow{3}{*}{$\begin{array}{l}\text { economically- } \\
\text { socially } \\
\text { backward areas }\end{array}$} & \multirow{3}{*}{$\begin{array}{l}\text { industrial } \\
\text { restructuring } \\
\text { areas }\end{array}$} & \multirow{3}{*}{$\begin{array}{l}\text { agricultural- } \\
\text { rural } \\
\text { development } \\
\text { areas }\end{array}$} & $\begin{array}{l}\text { areas hit by } \\
\text { severe } \\
\text { unemployment }\end{array}$ \\
\hline & $\begin{array}{l}\text { 106/1997. (VI. } \\
\text { 18.) Govt. } \\
\text { Decree }\end{array}$ & & & & & $\begin{array}{l}\text { areas hit by } \\
\text { persistent } \\
\text { unemployment }\end{array}$ \\
\hline $\begin{array}{l}\text { 30/1997. (IV. } \\
\text { 18.) OGY } \\
\text { Decision }\end{array}$ & $\begin{array}{l}\text { 19/1998. (II. 4.) } \\
\text { Govt. Decree }\end{array}$ & $\begin{array}{c}\text { complex } \\
\text { indicator } \\
\text { of } 28 \\
\text { indices }\end{array}$ & & & & \\
\hline \multirow[t]{2}{*}{$\begin{array}{l}\text { 24/2001. (IV. } \\
\text { 20.) OGY } \\
\text { Decision }\end{array}$} & $\begin{array}{l}\text { 91/2001. (VI. } \\
\text { 15.) Govt. } \\
\text { Decree }\end{array}$ & \multirow{2}{*}{$\begin{array}{l}\text { complex } \\
\text { indicator } \\
\text { of } 19 \\
\text { indices }\end{array}$} & \multirow[t]{2}{*}{$\begin{array}{l}\text { economically- } \\
\text { socially } \\
\text { backward areas }\end{array}$} & \multirow{2}{*}{$\begin{array}{l}\text { industrial } \\
\text { restructuring } \\
\text { areas }\end{array}$} & \multirow{2}{*}{$\begin{array}{l}\text { rural } \\
\text { development } \\
\text { areas }\end{array}$} & \\
\hline & $\begin{array}{l}\text { 64/2004. (IV. } \\
\text { 15.) Govt. } \\
\text { Decree }\end{array}$ & & & & & \\
\hline $\begin{array}{l}\text { 67/2007. (VI. } \\
\text { 28.) OGY } \\
\text { Decision }\end{array}$ & $\begin{array}{l}\text { 311/2007. (XI. } \\
\text { 17.) Govt. } \\
\text { Decree }\end{array}$ & $\begin{array}{c}\text { complex } \\
\text { indicator } \\
\text { of } 31 \\
\text { indices }\end{array}$ & $\begin{array}{l}\text { disadvantaged } \\
\text { micro-region }\end{array}$ & $\begin{array}{l}\text { the most } \\
\text { disadvantaged } \\
\text { micro-region }\end{array}$ & $\begin{array}{l}\text { the most } \\
\text { disadvantaged } \\
\text { micro-region } \\
\text { to be } \\
\text { supported by a } \\
\text { complex } \\
\text { programme }\end{array}$ & $\begin{array}{l}\text { temporary } \\
\text { beneficiary } \\
\text { micro-region }\end{array}$ \\
\hline $\begin{array}{l}\mathbf{5 6 / 2 0 1 1 . ~ ( V I . ~} \\
\text { 29.) OGY } \\
\text { Decision }\end{array}$ & \multicolumn{6}{|c|}{$\begin{array}{l}\text { Chapter } 4 \text { of the Parl. Decision is extended by Article 6a. as follows: } \\
\text { „6a. The most disadvantaged micro-region can be considered as a region with severe natural or } \\
\text { civilizational disaster, in which the elimination of damages and the normal operation of local socio - } \\
\text { economic life require a lasting, multi-annual development, where the development potential of the } \\
\text { region is severely restricted by the disaster for several years. }\end{array}$} \\
\hline \multirow[t]{2}{*}{$\begin{array}{l}\text { By reference to } \\
\text { the Fundamental } \\
\text { Law and the Act } \\
\text { on Regional } \\
\text { Development }\end{array}$} & $\begin{array}{l}\text { 290/2014. (XI. } \\
\text { 26.) Govt. } \\
\text { Decree on the } \\
\text { Classification } \\
\text { of Beneficiary } \\
\text { Districts }\end{array}$ & \multirow[t]{2}{*}{$\begin{array}{c}\text { complex } \\
\text { indicator of } \\
24 \text { indices }\end{array}$} & \multirow[t]{2}{*}{$\begin{array}{l}\text { beneficiary } \\
\text { district }\end{array}$} & \multirow[t]{2}{*}{$\begin{array}{l}\text { district in need } \\
\text { of development }\end{array}$} & \multirow{2}{*}{$\begin{array}{l}\text { district in need } \\
\text { of } \\
\text { development } \\
\text { with a } \\
\text { complex } \\
\text { programme }\end{array}$} & \\
\hline & $\begin{array}{l}\text { 106/2015. (IV. } \\
\text { 23.) Govt. } \\
\text { Decree }\end{array}$ & & & & & \\
\hline
\end{tabular}

Source: the author's own edition 
Map 1: Areas affected by the beneficiary classification having been in force since 2015 in Hungary

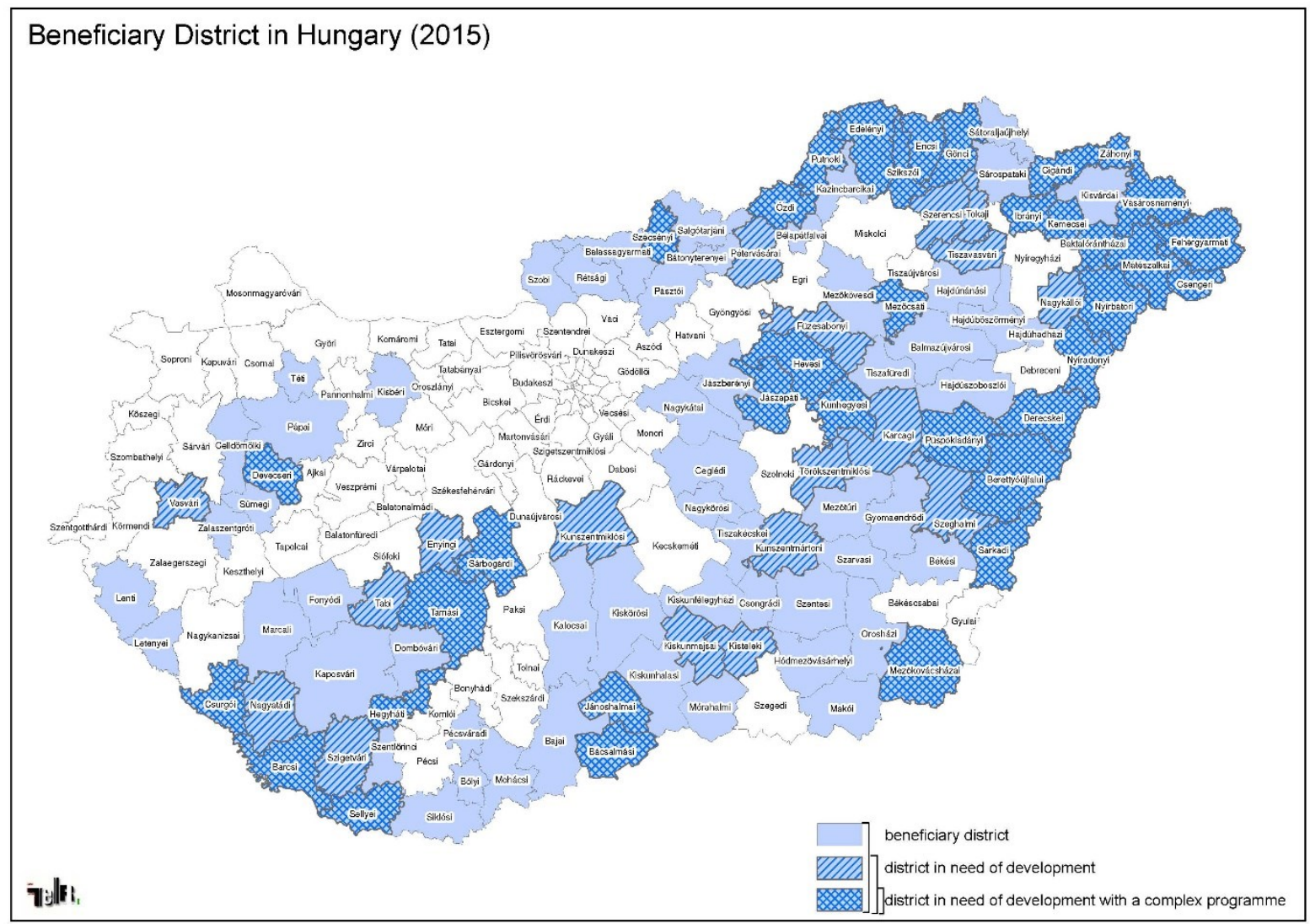

Source: TÉRPORT (The Spatial Information Portal System of Hungary): http://www.terport.hu/tematikusterkepek/kedvezmenyezett-jarasok-a-2902014-xi-26-korm-rendelet-szerint

The number of indicators used for the classification of beneficiary regions showed an upward trend (up to 31) by 2014. At the same time, "the methodological aspirations of the recent period indicate that the use of fewer indicators is just as satisfactory to locate disadvantaged settlements with a similar precision as the use of a large number of indicators." (Harcsa, 2014, p. 6). We have also faced such an opinion that "in extreme cases, even a single indicator, the basis of per capita income could be suitable for defining the most disadvantaged micro-regions. For example, out of 94 such micro-regions defined on the basis of 31 indices, 92 could be delimited by this single indicator in 2007." (Harcsa, p. 8), (András Nagy came to a similar conclusion Nagy, 2011 p. 13). It is also to be remembered that Community legislation uses only one indicator, GDP, for the "beneficiary" rating. Of course, this method is still subject to numerous criticisms, especially in terms of how far GDP can act as an indicator of disadvantaged or developed state. It is also a fact that the lowest measurable territorial unit of this single indicator is the county, which in itself confers a great deal on its own, by covering sometimes very significant - territorial differences within the county. 
Territorial delimitation and the definition of the purpose and indicators of territorial delimitation here face the question of an adequate territorial scale, which is a basic requirement of being capable for demonstrating and tracking the evolution of development and territorial processes. The EU's development policy, the scale of which is regional level (NUTS II) larger than county, is far less likely to serve as a suitable territorial unit of development. The institutional system for the 2014-2020 programming period transferred regional development competences to counties, from NUTS 2 to NUTS 3 level (Simó et al., 2018.) Spatial development competences have been transferred to counties from NUTS 2 to NUTS 3 level by the institutional system for the 2014-2020 programming period Our research experiences show that the regional scale is totally unsuitable for measuring real territorial differences, because regional averages confuse and overstate differences within the region, where relevant. (Even a single large city can convey an unrealistic picture of the development of the entire region, where the contribution to GDP, - for example, due to a car industry, a nuclear power plant or other investment less perceptible to any settlement in the region - far exceeds the average of other settlements in the region. Although 90\% of the region is undeveloped, $60 \%$ of the population lives in disadvantaged settlements, the regional level statistical "result" does not reflect this.) It is also a fact that the scale of spatial unit can particularly be important for rural development policy, capable of thinking not in a regional level but in a smaller territorial unit where territorial differences and their changes can be traced within the region. Rural development policy at Community level is much more focused on a territorial unit corresponding to the Hungarian micro-regional level (the so-called LAU-1 level in the Community nomenclature).

Based on the above, the question, that at Community level, what can be the obstacle to the assessment of actual territorial processes by introducing a single measurement system based on a number of indicators and data basically available to the Member States on LAU-1 level, may rightly arise.

In addition to the current system for measuring the GDP and using a regional scale, it would be useful to fine-tune the system at Community level, which could be more sensitive to monitoring the evolution of real regional processes. (Hungarian regulation - similarly to the dominant majority of opinions in domestic literature considers the district, micro-level level as evident in the case of the beneficiary classification.)

Fine-tuning can provide a possibility to monitor the effects of rural development policy and interventions promoting the development of rural areas at European level.

Differentiation is necessary because unfortunately, despite all the efforts at Community level, up to now there has not been formed consistency and cooperation between the various 
European development funds to facilitate the harmonious development of rural and urban areas. In practice, the predominance of differentiation and delimitation is much more dominant and as a consequence, particularly in Hungary, urban areas have far greater development resources and development opportunities. At the same time, cohesion policy at Community level provides information on convergence between the regions. This is in fact the result of the previously mentioned point-patterned development, whereby the regions' rural areas are not only unable to catch up, but rather their lagging process is accelerating. (It can be noted that investigation based not only on GDP provides far more details in a European comparison, where only three regions in Hungary are not part of the lagging regions.) (Report on lagging regions, 2017)

After touching on the issues of the adequate territorial unit, returning to the world of indicators, on the question concerning how many and which indicators would be reasonable to select, the literature provides a more general, but forward-looking, statement.

"The 'formal' professional opinions on disadvantaged settlements were fundamentally influenced by current policy expectations in the form of parliamentary decisions that have directed methodological development towards specific approaches" (Harcsa, 2014, p. 8). "...most often it was the more influential social strata and regions being in dominant position whose interests were determining the classification and measurement of development level..." (Gáspár, 2013, p. 51).

In any case, it is certain that the higher the number of indices assigned to the classification, the easier it is to change the previously formed order by manipulating some indicators. It also serves as an argument for the narrower indicator group that even up to $6+1$ variables can define the scope of lagging areas with a relatively higher security (MTA RKK, TERRA STÚDIÓ, VÁTI, 1999). As the number of indicators decreases, the room for manoeuvring narrows, which would - unobtrusively - make the change.

It is also important to emphasize that the aggregation of too many unweighted variables of a different nature weakens the distinctive character for simple numerical reasons and tends to equalize. An argument behind the use of less indicators may also be that the coexistence of the indicators used for the present - and the past - decade is more likely to be directed towards balancing rather than differentiating.

In addition to the quantity of indicators chosen, at least as much or more important is how they meet the expectations against the quality of indicators. The expectations - as it is seen from the text of the decision - focus primarily on the relationship to development. The extent to which it can be related to the level of development, the degree to which it is able to demonstrate the state of development and the degree of developmental disadvantage, are very 
difficult to define objectively and apply equally correctly and well established for more than three thousand settlements of the whole country. The selection of the indicators used therefore has an inevitability with some subjectivity (so it is good if the number of indicators is not too high, because the degree of subjectivity in the system can be proportionally reduced). At the same time, for some of the indicators - a public agreement - a consensus - has emerged from the point of view that they have always been part of the set of indicators (or in better case of a system) that decision-makers were trying to assign to development level. Most of these indicators are related to income relations (personal income tax), reflecting unemployment i.e. employment situation (with different ratio indicators) or characterising migration processes.

Among the indicators currently used, there are elements where the close relationship to development level is highly questionable. These include the so-called urbanity index. Although districts with a dominant urban centre are most likely to be more developed in urban disadvantaged areas, it is easy to see, for example, by the examples of formerly significant but declining industrial cities that the overweight presence of urban population itself is not fortunate to regard as a development factor. Moreover, other equally, or even more acceptable trial calculation modes ${ }^{2}$ for the urbanity index show that a slight content-modification of only one of the 24 components of the currently used complex indicator may significantly change the outcome of the district ranking and thus the set of beneficiary districts.

Another objectionable indicator is the currently used - for the period 2014-2020 infrastructure-environmental indicator group, which refers to the proportion of homes involved in waste disposal. Because according to the Act on Local Governments in Hungary and sectoral legislation, this public service is obligatory in every settlement, its presence is considered as an incorrect indicator of development. (This is not only justified by the statutory obligation, but also by the fact that the service itself operates under national coverage where the area excluded from this service can be regarded as an exception.)

The above examples, on the one hand, indicate the problems of currently used indicators, the need for revision, on the other hand the consequences of using "multiple indicators", the sensitivity of delimitation results and the possibility of their distorsion of reality, which is basically due to the consequences of the index selection. (One of the greatest shortcomings of the present Hungarian practice of delimitation can be mentioned as the declaration of the district of Komló "advanced", being a former mining zone that still has not recovered from its

\footnotetext{
${ }^{2}$ The Hungarian legal regulation only takes into account a simplified population/territory formula for population density at the settlement level. Instead, we used a widely accepted and more appropriate GIS grid-based computation to identify the urban part of a district in the test calculation.
} 
depressed status since the closure of mines. At the same time, its neighbouring districts have received beneficiary status with traditionally favourable economic conditions and significant investments, well-known over Hungary (districts of Bóly and Mohács).

PRINCIPLE 3: The method used to calculate the complex indicator should be simple and transparent so that the classification can be easily checked by the representatives of municipalities and districts

Complying with or even strengthening this principle is reasonable even if professionals, in order to improve the functioning of the system, are committing themselves to more complex solutions (Pénzes, 2014, pp. 72-73). The examination of calculation methods - due to scope constraints - cannot be a part of this study, but it is necessary to draw attention to the necessity of completing the scope of the delimitation calculations in such a way that it could meet the delimitation requirements of any development programme. This need may be barely questionable in the knowledge of the purpose, the function and mission of the Hungarian National Development and Regional Development Concept (OFTK) (Salamin et al., 2014). What makes this issue topical since 2007, it is not the regional development programme but the Rural Development Programme (VP), which is part of the rural development system; it works with such a system which settlements with a population of more than ten thousand inhabitants are not part of. It is not a novelty that such calculations have been made that excluded district seats from the districts (Faluvégi, 1995) and computed development comparisons on such a basis. In case of VP however, not district seats are taken into account as the goal here is to measure the degree of development of rural areas, and not their comparison with or without their district seat. Independent delimitation of the VP seems to be reasonable because the current classification system creates an unfair situation, which means that a particular rural area - only due to having a settlement with a population of over ten thousand inhabitants but not included in the Rural Development Programme - receives low intensity subsidization (e.g. $65 \%$ ). At the same time, the neighbouring district with no settlements with a large population of over ten thousand inhabitants that would distort the data of the surrounding countryside in the wrong direction may receive up to $95 \%$ intensity subsidization. (This is particularly disadvantageous for small settlements with modest capital resources.)

By excluding the settlements with ten thousand inhabitants, as a result of the current classification based on the current calculation method and indicators, we calculated 118 beneficiary districts instead of the original 109. 
Based on Table 3 it is possible to compare the mean values and deviations of the components of the complex indicator calculated by excluding cities.

Table 3 The characteristics of the complex indicator and its components by excluding towns with ten thousand inhabitants and bigger cities

\begin{tabular}{|l|c|c|c|c|}
\hline \multirow{2}{*}{} & \multicolumn{2}{|c|}{ Average } & \multicolumn{2}{c|}{ Deviation } \\
\cline { 2 - 5 } & $\begin{array}{c}\text { with the } \\
\text { inclusion of } \\
\text { cities }\end{array}$ & $\begin{array}{c}\text { with the exclusion } \\
\text { of cities with over } \\
\text { 10 thousand } \\
\text { inhabitants }\end{array}$ & $\begin{array}{c}\text { with the } \\
\text { inclusion of } \\
\text { cities }\end{array}$ & $\begin{array}{c}\text { with the exclusion } \\
\text { of cities with over } \\
10 \text { thousand } \\
\text { inhabitants }\end{array}$ \\
\hline Social situation & 52.0 & 39.8 & 19.1 & 14.4 \\
\hline Housing and living conditions & 40.2 & 34.3 & 15.8 & 13.6 \\
\hline Local economy & 38.0 & 32.1 & 15.8 & 11.0 \\
\hline Infrastructure & 52.2 & 43.2 & 18.0 & 11.4 \\
\hline COMPLEX INDICATOR & 45.6 & 37.3 & 16.0 & 11.0 \\
\hline
\end{tabular}

Source: the authors' own edition.

Table 3 clearly shows that as a result of calculation with the exclusion of big cities, not only the average has fallen, but the deviation of the indicator has also decreased considerably. Therefore, the figures indicated on national level for rural population appear to be more homogeneous. This seems to verify the assumption that the countryside alone is by far more homogenous - and at the same time less developed - than calculated with cities with over 10 thousand inhabitants. This confirms the statement that during the allocation of rural development resources, due to the presence of cities with over ten thousand inhabitants, certain districts are unfairly disadvantaged. It can also be noted that by the application of settlement level development indicator the spectacular difference on district level can no longer be perceived, as the exclusion of the 143 cities would only make a hardly noticeable change in the average and deviation indicators of the total 3154 settlements.

\section{THE SET OF PROPOSED INDICATORS AND SOME RESULTS OF TEST CALCULATIONS}

There are additional arguments that can be formulated for simplifying the calculation based on the current 24 indicators. The first is the difficulty of collecting data, since the component indicators are derived quantities and can only be produced with the help of additional basic data. At present, 60-70 settlement baseline data are needed to prepare the computation, and moreover, several of them are not found in the standard publications of KSH (Central Statistical Office of Hungary). This number is unnecessarily high for defining the development level of settlements. With the inclusion of basic dimensions - income, unemployment, education, transport - the top and bottom of the ranking can reliably be selected. 
It is well known that, in comparison with the beneficiaries' classification regulated by the current legislation, researchers have tried to rethink, quantify and re-interpret the issue of regional development level with the application of many other indicators and methods (Koós, 2015; Pénzes, 2014). There is no room for evaluating the different methods and results here, but it can be stated that they seem to have limited possibilities to provide a definitive and reassuring solution from a development policy point of view. The following indicators and methodology will not fundamentally change this situation, but they provide some other results proceeding from a different baseline.

Below, compared to the official use, significantly reduced calculations using a nine component set of indicators will be presented. When selecting indicators, we rely on existing sets, but in selecting specific indicators we paid particular attention to aspects such as time resistance, tight correlation with development, independence, and the ambition to minimizing indicators. The selection criteria may be less controversial, but there is no doubt that the selected indicators carry a kind of subjectivity just as in any other case, which is inevitable. This is a direct consequence of the fact that there is no equally acceptable, perfect solution for everyone.

\section{Recommended indicator sets and indicators}

Social situation: (1) Migration difference per thousand (average of the last five years), people; (2) The number of people per 1000 permanent residents of active age receiving social benefits (regular benefits for social assistance and employment), people;

Housing and living conditions: (3) The ratio of homes built during the last five years from housing stock at end of period, \%; (4) Personal tax base income per inhabitant, thousand HUF;

Local economy and labour market: (5) Percentage of people aged 18 years and over, with at least high school graduates, \%; (6) Number of jobs per thousand permanent residents, pcs; (7) The local governments' ratio of local tax revenue from the year's total revenues, $\%$;

Infrastructure: (8) The average travel time from the district's settlements to the county seat on road, minutes; (9) The ratio of settlements reaching a highway ramp in maximum 15 minutes, $\%$.

The test calculation method was entirely consistent with the method defined by the law currently in force. One of the reasons was that it is not the method but rather the set of indices (indicators) used that seems to be problematic, and the other reason is the necessity to demonstrate that the same method with changed (changeable) indicators could produce closer to reality values. According to the law, evaluation is based on the mean value of the four group indicators shown in Table 1, that is using the following formula: 
$f i=\frac{1}{m} \sum_{i=1}^{m} f a_{i}: \quad$ where

$f i$ : denotes the complex index

$f a_{i}$ : denotes the $i$-th group indicator $(i=1, . ., m)$

$m:$ is the number of group indicators, and before averaging all raw indicators are normalized to the $[0,100]$ interval by the linear transformation $y_{i}=100\left(x_{i}-x_{\min }\right) /\left(x_{\max }-x_{\min }\right)$.

As a result of test calculations the most important changes were as follows. By applying the new complex indicator the districts of Devecser $(183 / 146)^{3}$, Mezőcsát (182/159) and Derecske $(178 / 151)$, positioned in the close proximity of the most disadvantaged group in need of development by a complex programme, significantly improved their ranking and were eliminated from this group. On the other hand, the districts of Sátoraljaújhely (105/174) and Sárospatak (121/164) were significantly backsliding and thus became members of the most disadvantaged group.

Examining the upper part of the group in need of development, the districts of Kiskunmajsa (146/114), Kunszentmiklós (147/123), Füzesabony (152/118), Kistelek (157/106), Enying $(159 / 139)$ and Tab (161/134) have received a significantly better ranking in the new classification system and thus were eliminated from the group in need of development. At the same time the districts of Rétság (118/148), Balmazújváros (131/153), Tiszafüred (133/154), Kisvárda (134/157) and Hajdúhadháza (139/162) received much worse evaluation and consequently would become members of the group in need of development.

As regards the districts positioned near the beneficiary thresholds, the new calculation with a big difference promoted them into a better position and thus excluded the districts of Bóly (116/68), Hajdúböszörmény (98/73), Jászberény (92/66) and Hajdúszoboszló (91/74) from the beneficiary group. On the other hand, the new indicator ranked much more disadvantageous, and thus put into the circle of beneficiaries the districts of Komló (87/132), Bonyhád (77/108), Nagykanizsa (74/90), Zirc (72/101), Kapuvár (71/92), Tapolca (67/96), Várpalota (65/93) and Ajka (51/80).

What settlements and districts are really interested in, is of course not the name or the result of their statistical delimitation. For them the most important aspect is the accessibility of development resources. The solution is also known from Community legislation that regions that are more developed at European level are eligible for smaller amount of resources and the

\footnotetext{
${ }^{3}$ The two numbers in parentheses refer to the official and the newly calculated ranks of the 198 items, respectively.
} 
intensity of their subsidization is also lower. Hungary - based on its beneficiary delimitation results - added further legal requirements to the territory-based regulations:

- the basic eligibility criteria for certain grants (tenders) is that their application should be submitted from the territory of the beneficiary district;

- the intensities of subsidisation can be differentiated according to the ranking, which may be up to $75 \%, 85 \%, 95 \%$ or $100 \%$ for non-market actors.

- in the case of the LEADER programme, of the organizations organized for one or two districts those seared in beneficiary districts had a larger source of funds;

For local governments, entrepreneurs, but even for the whole population it does really matter, how such a beneficiary status resulting from territorial delimitation progresses and changes during time.

\section{THE BENEFICIARY STATUS IN THE "CAPTURE OF STATISTICS"}

Despite the best intention of legislators, the fact that statistics are only a tool that can bring us closer to the goal of characterizing the development of the different territorial units in some way, in pursuit of objectivity, should not be ignored. We must be aware of the constraints of statistics (the reality content, the accessibility of baseline data, distortions caused by calculations, etc.). Statistics alone are not always and not fully able to determine the level of development or of disadvantageous situation. As it has already been said a quarter of a century ago, “... by the 'skilful' choice of methods, for example, by virtue of the same phenomenon, it can be 'demonstrated' that territorial inequalities (differentiation) increase, but also that they decrease (levelling)" (Nemes, 1990, p. 133). Similar sceptical statements can be found in many publications, even in their titles, e.g. in Huff (1954) "How to Lie with Statistics?" and in Deakin et al. (2002) "The Centroid? Where would you like it to be?"

Due to the problems of the basics of the statistical calculations currently applied, it is possible to formulate a requirement to be stated in the resolution of the parliamentary decision that it is necessary to undertake preliminary studies based on empirical tests and methods of other disciplines prior to statistical measurements. In fact, this is not significantly different from the baseline and evaluation activities related to the EU programming period and each operational program, which are called ex-ante, mid-term and possibly ex-post evaluations. These basic and assessment studies - in the form of reality or validity tests - may be able to confront calculation based statistical data with experiential facts. 
It can be defined as a basic requirement - at the level of a not yet passed parliamentary decision - that the developmental classification based on statistical calculations and nonstatistical methods should not conflict with each other. The formulation of a system based on statistical data and models and on empirical, non-statistical methods can be defined as a need that would be desirable in the near future - for preparing for the post-2020 period - with broad professional co-operation and consensus. There is no doubt that statistical methods can have a relatively long history and offer a fairly wide range of solutions in territorial delimitation. At the same time, the validation of statistical results, or the foundation of statistical calculations, is a missing element that is definitely needed to consolidate or to regain the confidence of development actors.

\section{CONCLUSION}

The principles that have always been the framework for delimiting the beneficiary regions should be preserved, but at the same time, their expansion seems to be reasonable by elements that ensure the independence of the indicators used and that statistical calculations cannot lead to a situation that is clearly contradictory.

The simplification of the range of indicators used in the delimitation and of the data used (the reduction of their number) is in any case reasonable because it can contribute to objectivity and to reducing the possibility of manipulation. The long-term comparability ensuring the efficiency and measurability of interventions can only become reality if the data used do not differ from each other.

As long as there exists a support system at national level but not for all settlements in the country (e.g. Rural Development Programme), - to avoid unfair and unrealistic situations - the classification of development should be done in these areas as well.

At European level, in addition to the GDP-based and regional-scale delimitation methodology, it would be particularly important to institutionalize the territorial delimitation system focusing on smaller territorial units (LAU 1) and multiple indicators, in order to trace real territorial processes. It is only small territorial units that can be suitable for evaluating socio-economic changes in rural areas.

The efficiency of development policy interventions can only be achieved by territorial delimitation capable of creating territorial focus and concentration matching with the goals. The necessity of testing delimitation methods for this purpose during the programming period should be included in legal regulation as well. 


\section{REFERENCES}

Bakaric, I. R. (2005). Uncovering regional disparities - the use of factor and cluster analysis. Economic Trends and Economic Policy, 105, 52-77.

Boldrin, M. P., \& Canova F. (2001). Inequality and convergence in European regions: reconsidering European regional policies. Economic Policy. 16, 207-253.

Booysen, F. (2002). An overview and evaluation of composite indices of development. Social Indicators Research, 59(2), 115-151.

Bossel, H. (1996). Deriving indicators of sustainable development. Environmental Modeling and Assessment, 1(4), 193-218.

Bossel, H. (1999). Indicators for sustainable development: Theory, method, applications. A report to the Balaton Group. International Institute for Sustainable Development.

Copust, A. K., \& Crabtree, J. R. (1996). Indicators of socio-economic sustainability: An application to remote rural Scotland, Journal of Rural Studies, 12, 41-54.

Davies, R. (2014). Measuring well-being and progress: Looking beyond GDP, EPRS.

Deakin R. E., Bird S. C., \& Grenfell, R. I. (2002). The Centroid? Where would you like it to be?. Cartography, 31(2), 153-167.

De Smedt, M. (2013). Measuring subjective issues of well-being and quality of life in the European statistical system, Social Indicators Research, 114(1), 153-167. DOI:10.1007/s11205-013-0389-5

Dhongde, S., \& Haveman, R. (2015). Multi-dimensional poverty index: An application to the United States.

Faluvégi, A., \& Tipold, F. (2009). Kedvezményezett települések az új országgyülési határozat mutatói alapján - próbaszámítás [Beneficiary settlements based on the indicators of the new parliamentary decision - trial calculation]. Területi Statisztika, 3, 264-279.

Faluvégi, A,. \& Tipold, F. (2012). A társadalmi, gazdasági és infrastrukturális szempontból elmaradott, illetve az országos átlagot jelentősen meghaladó munkanélküliséggel sújtott települések [Socially, economically and in infrastructural sense disadvantaged settlements and hit by unemployment significantly above the national average]. Területi Statisztika, 3, 278-290.

Faluvégi, A. (1995). Az elmaradott térségek lehatárolásának módszerei [Methods for delimiting backward regions]. Statisztikai Szemle, 73.(7), 571-590.

Farkas, S. (2018): Changing intermediary system of repayable EU Funds in Hungary (20072013, 2014-2020). Deturope, 10(3), 180-198.

Foster J., \& Sen, A. (1997). On economic inequality. Oxford: Clarendon Press.

Gáspár, T. (2013): A regionális fejlesztés új megközelítésben [Regional development in a new approach]. Gazdálkodás. 58(1), 41-57.

Hagerty, M. R., Cummins, R. A., Ferriss A. L., Land, K., Michalos, A. C., Peterson, M., Sharpe, A., Sirgy, J., \& Vogel, J. (2001). Quality of life indexes for national policy: Review and agenda for research, Social Indicators Research, 55, 1-96.

Hair, J. F., Black, W. C., Babin, B. J., \& Anderson, R. E. (2010). Multivariate data analysis: A global perspective. New Jersey: Pearson Prentice Hall.

Hák, T., \& Janoušková, S. (2013). "Beyond GDP” indicators in the Czech Republic. Statistika, 93(2), 86-99.

Harcsa, I. (2007). Magyarország a társadalmi jelzőszámok tükrében [Hungary in the mirror of social indicators]. In Kolosi, T.,Tóth, I. Gy., \& Vukovich, Gy. (Eds.), Társadalmi riport. 2007 (pp. 471-498). Budapest: TÁRKI. 
Harcsa, I. (2014). I. A települések fejlettségét mérö mutatószámok. II. A települési-térségi sajátosságok és a család/háztartás szerkezet közötti kapcsolat [Indicators measuring the development level of settlements. II. Relationship between the local-regional characteristics and the family / household structure]. Budapest: Központi Statisztikai Hivatal. (Mühelytanulmányok).

Huff, D. (1954). How to Lie with Statistics. New York: Norton.

Jenkins, S. P., \& Micklewright, J. (Eds.) (2007). Inequality and Poverty Re-Examined. Oxford: Oxford University Press.

Koós, B. (2015). A szegénység és depriváció a magyar településállományban az ezredfordulót követően - avagy kísérlet a települési deprivációs index létrehozására [Poverty and deprivation in Hungarian settlements after the Millennium - an attempt at creating a rural deprivation index]. Tér és Társadalom, 29(1), 53-68.

Kutscherauer, A., Fachinelli, H., Hučka, M., Skokan, K., Sucháček, J., Tománek, P., \& Tuleja, P. (2010). Regional disparities in regional development of the Czech Republic. Technical University of Ostrava.

Lepenies, P. (2016). The power of a single number : a political history of GDP. New York: Columbia University Press.

Lipshitz, G. (1993). The main approaches to measuring regional development and welfare, Social Indicators Research, 29(2), 163-181.

Mabogunje, A. L. (1980). The development process: A spatial perspective. London: Hutchinson.

Marchante A. J., \& Ortega, B. (2006). Quality of life and economic convergence across Spanish regions, 1980-2001, Regional Studies, 40(5), 471-483. DOI:10.1080/ 00343400600757460

MTA RKK, TERRA STÚDIÓ, VÁTI (1999). A kedvezményezett térségek besorolása feltételrendszerének felülvizsgálata. - Összefoglaló zárójelentés [Revision of the criteria for the classification of beneficiary areas. - Summarizing final report] (szerk. Csatári B.). Kecskemét: MTA RKK ATI.

Nagy, A. (2011). A kedvezményezett térségek besorolásának alakulása, a lehatárolások módszertanának sajátosságai [The evolution of the classification of the beneficiary regions, the characteristics of the methodology of the delimitations]. In Területi Statisztika, 2, 148-160.

Nemes Nagy, J. (1990). Területi kiegyenlítődés és differenciálódás Magyarországon [Territorial equalization and differentiation in Hungary]. Földrajzi Értesitö, 39(1-4), $133-149$.

OECD (2008). Handbook on constructing composite indicators: Methodology and user guide, OECD.

Özaslan, M., Dincer B., \& Özgür, H. (2006). Regional disparities and territorial indicators in Turkey: Socio-Economic Development Index (SEDI), ERSA conference papers ersa06p858, European Regional Science Association.

Pénzes, J. (2014). Periférikus térségek lehatárolása - dilemmák és lehetöségek [Delimiting peripheral areas - dilemmas and opportunities]. Debrecen: Didakt Kft.

Pieterse, J. N. (2010). Development theory. London: Sage.

Saisana, M., Saltelli, A., \& Tarantola, S. (2005). Uncertainty and sensitivity analysis techniques as tools for the quality assessment of composite indicators. Journal of the Royal Statistical Society. Series A (Statistics in Society), 168(2), 307-323. 
Salamin, G., Kígyóssy, G., Borbély, M., Tafferner, B., Szabó, B., Tipold, F., \& Péti. M. (2014). Az Országos Fejlesztési és Területfejlesztési Koncepció és a 2005-ös országos területfejlesztési koncepció érvényesítésének tapasztalatai [Experiences in the implementation of the National Development and Regional Development Concept and the 2005 National Regional Development Concept]. Falu, város, régió, 20(1), 5-24.

Salvatia, L., Zittia, M., \& Carlucci, M. (2016). In-between regional disparities and spatial heterogeneity: a multivariate analysis of territorial divides in Italy. Journal of Environmental Planning and Management, 60, 997-1015.

Scherbov, S., \& Ediev, D. (2011). Significance of life table estimates for small populations: Simulation-based study of estimation errors. Demographic Research, 24, 527-550.

Sen, A. (1987). The Standard of living. (Hawthorne G). Cambridge University Press, Cambridge.

Sen, A. (1999). Development as freedom. New York: A. A. Knopt.

Simó, B., Gordos, T., \& Józsa, V. (2018), Regional instititutions at the doorstep of post 2020 cohesion policy - status report from Hungary. Deturope, 10(3) 14-32.

Somlyódyné Pfeil, Edit (2017). Chances of Effective Urban Policy in Hungary Under the Influence of the European Cohesion Policy. Deturope, 9(3), 141-161.

Stamenković, M., \& Savić, M. (2017). Measuring regional economic disparities in Serbia: Multivariate statistical approach. Industrija, 45, 101-130.

Stiglitz, J. E., \& Walsh, C. E. (2006). Economics. 4th ed. New York: W. W. Norton \& Company, Inc.

Stiglitz, J. E., Sen, A., \& Fitoussi, J-P. (2009). Report by the Commission on the measurement of economic performance and social progress. https:/ec.europa.eu/eurostat/documents/ 8131721/8131772/Stiglitz-Sen-Fitoussi-Commission- report.pdf

The lagging regions report, Submitted by: Applica sprl, Cambridge Econometrics, wiiw, April 2017.

UN (2003). Indicators for monitoring the Millennium Development Goals. UN, New York.

Vrtenová L., Sobotka, M., \& Malá, L. (2009). Measurement of regional disparities and economic competitiveness of regions.

Widuto, A. (2016). Beyond GDP: Global and regional development indicators, EPRS.

Wishlade, F., \& Yuill D. (1997) Measuring disparities for area designation purposes: Issues for the European Union. University of Strathclyde. 